(๑) Academy of Management Review

2004, Vol. 29, No. 4, 653-669.

\title{
A RHETORICAL THEORY OF DIFFUSION
}

\author{
SANDY EDWARD GREEN, JR. \\ University of Southern California
}

\begin{abstract}
I use rhetorical theory to reconceptualize the diffusion of managerial practices. Specifically, I argue that the diffusion of a practice depends on the discursive justifications used to rationalize it. When such justifications are accepted and taken for granted, a practice reaches a state of institutionalization. Furthermore, I propose that changes in justifications and diffusion provide a basis for explaining institutionalization as both a process and a state. I then develop several propositions from this model.
\end{abstract}

The management field has witnessed the rise and fall of many managerial practices, including sensitivity training, quality circles, and reengineering (Corson, Lanier, Carson, \& Guidry, 2000; Eccles, Nohria, \& Berkley, 1992). Most management innovations arrive and dissipate quickly (Abrahamson \& Fairchild, 1999), while a few thrive and diffuse broadly throughout the business community. Although several theories explain variation in the diffusion of managerial practices (Abrahamson, 1991; O'Neill, Pouder, \& Buchholtz, 1998; Rogers, 1995), critics argue that these explanations often emphasize realist concerns at the expense of linguistic considerations (Hirsch, 1986; Strang \& Meyer, 1994). Therefore, in this article I use neoinstitutional theory, because it emphasizes the role of language or discourse in the diffusion process (Strang \& Meyer, 1994).

Proponents of the neoinstitutional perspective view the spread of managerial practices as a salient organizational act that must make sense to decision makers and must satisfy the institutional environment (Scott, 1995; Tolbert \& Zucker, 1996). Managerial practices are accompanied by legitimating managerial discourse, which explains how practices help managers rationally pursue valued goals (Friedland \& Alford, 199l; Strang \& Meyer, 1994). For example, the management fashion variant of neoinstitutionalism (Abrahamson, 1996; Abrahamson \& Fairchild, 1999; Kieser, 1997) describes how managers use

I thank Jeffrey Ford and three anonymous reviewers for their helpful comments on earlier drafts of the manuscript. I also thank Craig Keys, Thomas Cummings, Nitin Nohria, Jay Lorsch, Brian Joseph, Benjamin Berger, Paul Adler, and Ian Mitroff. All remaining errors and omissions are entirely my own. discourse to communicate to organizational stakeholders that the adoption of a given practice complies with norms of rationality and norms of progress (Abrahamson, 1996; Abrahamson \& Fairchild, 1999). Thus, discourse shapes decisions about the adoption and wider diffusion of managerial practices (Abrahamson \& Fairchild, 1999; Strang \& Meyer, 1994).

Although neoinstitutional theory includes a role for discourse, two key problems remain. First, it suggests a model of diffusion that is inherently adaptivist (Hasselbladh \& Kallinikos, 2000). It shifts rational adaptation from the need to acquire resources in the technoeconomic environment to the need to conform normatively to the social environment (Hasselbladh \& Kallinikos, 2000; Hasselbladh \& Theodoridis, 1997), and it fails to explain why those needs exist or become influential or why a particular structure fulfills the need in question (Perrow, 1993). Second, neoinstitutional theory focuses on how institutions constrain actors at the expense of explaining how actors create institutions (Barley \& Tolbert, 1997; Zucker, 1987). Culture and discourse restrict the opportunities and alternatives available to actors, yet the ways in which actors' choices intentionally modify and shape institutions are not fully explained (Barley \& Tolbert, 1997). The result is a view of discourse and its relation to diffusion that is too passive and oversocialized- $\alpha$ view that explains the homogenization of the supraorganizational field but ignores agency, deviance, or political adaptation (Friedland \& Alford, 1991). This view fails to explain the patterns of institutional arenas or the conditions under which new institutional forms develop or are deinstitutionalized (Fried- 
land \& Alford, 1991; Greenwood, Suddaby, \& Hinings, 2002; Powell \& DiMaggio, 1991).

The cause and solution to these problems may rest with the ways in which discourse and its relationship to social action are conceptualized (Alvesson \& Körreman, 2000; Astley \& Zammuto, 1992; Gergen \& Thatchenkery, 1996). Rhetorical theory has been underutilized in organizational studies and, thus, may contribute to this field of inquiry. The central purpose of this article is to introduce rhetorical theory into the study of diffusion and demonstrate its utility for reconceptualizing discourse and social action. Rhetoric is a type of instrumental discourse used to persuade audiences, reach reliable judgments or decisions, and coordinate social action (Bizzell \& Herzberg, 1990; Gill \& Whedbee, 1997; Herrick, 2001). Rhetorical theory emphasizes how social actors' cognitive limits enable language to shape both the means and ends of their actions (Bizzell \& Herzberg, 1990; Guthrie, 1993; Kerferd, 1993; Richards, 1965). Through rhetoric, actors produce and assign meaning, constructing both their identities and the world (Billig, 1996; Booth, 1974; Quinn, 1996).

A rhetorical perspective suggests that managers play an active role in the diffusion process, because what managers say and how they say it matter a great deal (Eccles et al., 1992; Elsbach, 1994; Pfeffer, 1981). This perspective reconceptualizes diffusion as a product of rhetoric, because rhetoric con influence the motives driving firms to adopt innovations and shape the social structure through which those practices diffuse. Conceptualizing diffusion as a rhetorical process gives support to ideas held by management scholars who conceptualize the manager as rhetor (Eccles et al., 1992). This view emphasizes the linguistic origins of rationality and institutions. To rationalize is to give discursive reasons for actions; to institutionalize is to accept and take these reasons for granted. This makes language central to understanding variations in the diffusion and institutionalization of managerial practices and suggests a more active conceptualization of discourse and social action.

In this article I first describe the basic assumptions underlying a rhetorical perspective and then develop a rhetorical theory of diffusion. My central argument is that the type and sequence of discursive justifications determine the speed and extent of diffusion that a practice achieves and, ultimately, shape the degree of taken-for-grantedness that the practice attains. Finally, I discuss the implications of this perspective for theory and research.

\section{A RHETORICAL THEORY OF DIFFUSION}

In this section I develop a rhetorical theory of diffusion. I first describe the rhetorical perspective and then reconceptualize diffusion as a product of rhetoric. Specifically, discursive justifications establish the appropriateness and rationality of adoption and, ultimately, its degree of taken-for-grantedness. I use this rhetorical conception of diffusion to develop a proposition that differentiates the breadth of diffusion from the degree of institutionalization. Finally, I elaborate on what this means for our understanding of institutions, institutionalization, and institutional change.

\section{A Rhetorical Perspective}

The linguistic turn in organizational studies emphasizes the vital role of language in understanding organizations (Alvesson \& Kärreman, 2000; Dandridge, Mitroff, \& Joyce, 1980; Ford \& Ford, 1995; Pondy \& Mitroff, 1979; Zald, 1996). Previous research has shown that managers are essentially discursive beings, spending twothirds to three-fourths of their time engaged in verbal activity (Mintzberg, 1973). Managers use this constant verbal activity to gather information, develop shared understandings of the world, and persuade individuals to contribute to collective purposes, such as the adoption and implementation of new practices. Managers hear and use all kinds of arguments to elicit action and describe the world. However, most managers are unaware of the ways in which their language influences social action (Eccles et al., 1992).

Several theories, ranging from discourse analysis (van Dijk, 1997; Fairclough, 1992; Grant, Keenoy, \& Oswick, 1998) to social construction (Berger \& Luckmann, 1966; Gergen \& Thatchenkery, 1996; Weick, 1972), address the relationship of language to social action. Recently, organizational researchers have increased their interest in rhetorical theory as an additional lens through which to understand organizational actions and phenomena (Äbrahamson, 1997; Abrahamson \& Fairchild, 1999; Barley \& Kunda, 1992; 
Eccles et al., 1992; Gill \& Whedbee, 1997; Huff, 1983; Watson, 1995; Zbaracki, 1998).

Although rhetorical theory is broad and complex, the rhetorical perspective I use here incorporates the strong compatibilist perspective, as well as many of its underlying assumptions and goals (O'Neill, 1997). In the compatibilist perspective, reason and rhetoric are compatible and inextricably linked, because reason encompasses both the logic of demonstrative argument-premises that are self-evidently true-and the rhetoric of dialectical argumentpremises based on endoxa or opinions that are generally accepted (O'Neill, 1997). For the strong compatibilist, the inseparability of rhetoric and reason undermines traditional notions of objective truth and atomistic instrumental rationality-not to embrace relativism or irrationalism but to advocate an embedded and intersubjective rationality (McCloskey, 1998; O’Neill, 1997; Quinn, 1996).

\section{The Role of Rhetoric in Diffusion}

A rhetorical perspective that denies a distinction between reason and rhetoric may have profound implications for theories of diffusion. Most models of diffusion suggest that adoption of new practices and structures is driven by the intrinsic merits of the innovation and/or the characteristics of potential adopters (King \& Kugler, 2000; Rogers, 1995; Strang \& Macy, 2001). These perspectives underemphasize the role of rhetoric in the diffusion process (Abrahamson \& Fairchild, 1999; Hirsch, 1986; King \& Kugler, 2000; Strang \& Meyer, 1994). Actors are seen as adopting new practices and structures because they are effective (Strang \& Macy, 2001). Yet such views rest on the assumption that new practices do not actually have to be effective-actors only have to believe they are beneficial (Krackhardt, 2001; Strang \& Macy, 2001). A rhetorical view asserts that these beliefs do not emerge within a social vacuum; they are rhetorically shaped and promoted by organizational actors (King \& Kugler, 2000; Zbaracki, 1998). Thus, managers championing the adoption of new practices provide discursive justifications that rationalize and legitimize the new practices' adoption (King \& Kugler, 2000; Strang \& Meyer, 1994; Tolbert \& Zucker, 1996). Moreover, new proctices and structures may only be efficient and effective when supporting rhetoric rationalizes the usefulness of their adoption (Hirsch, 1986).

From a rhetorical perspective, such rationality is influenced by our ability to give reasons and, thus, link claims with justifications. Specifically, managers, in conversation with themselves and others, rationalize the adoption of managerial practices. This formulation resonates with arguments that rationality is discursively produced (Garfinkel, 1967; Gergen, 1994; Gergen \& Thatchenkery, 1996; Habermas, 1984; Quinn, 1996; Rorty, 1980; Wittgenstein, 1963). To be rational is to make persuasive sense. Accordingly, the more persuasive the discursive reasons supporting a managerial practice, the more rational its adoption. Moreover, as these reasons become more accepted and taken for granted, managerial practices become more institutionalized.

\section{Justifying Diffusion and the Production of Taken-for-Grantedness}

The main concern in a rhetorical theory of diffusion is how variation in discursive reasons persuades actors to adopt new practices and how, over time, the persuasiveness of these justifications shapes the way practices become taken for granted. This emphasizes the importance of taken-for-grantedness as a direct product of persuasiveness. Taken-for-grantedness is a phenomenological concept with many different connotations (Berger \& Luckmann, 1966; Jepperson, 1991; Zucker, 1991). Here, it means "to accept until further notice our knowledge of certain states of affairs as unquestionably plausible" (Schutz, 1962: 326). Rhetorical theory suggests that as the persuasiveness of discourse increases, the production of taken-for-grantedness increases.

Before a managerial practice can become taken for granted, it must first make sense. Sensemaking involves justifying a practice within an argumentative or linguistic context (Bakhtin, 1981; Billig, 1996; Perelman \& Olbrechts-Tyteca, 1969). Justifications establish appropriateness and rationality (Lamertz \& Baum, 1998); they legitimate and connect a practice to nature and reason (Douglas, 1986). Justifications are actively developed from endoxa, or that which is commonly believed and taken for granted (Aristotle, 1991; Herrick, 2001). Specifically, a manager hoping to justify the adoption of a new practice scans the commonly held assumptions 
or "taken-for-granteds" of his or her audience to produce justifications that support his or her claim about the practice. These justifications are then used by managers to shape the production of that which will be taken for granted in the future. This rhetorical fromework provides a view of how managers actively shape yet are simultaneously influenced by their symbolic environments.

Only individuals make justifications; however, we can conceptualize justifications as representing the dominant concerns of individuals in firms, classes, or industries. Thus, an industry might make a justification through individuals' expression of a dominant or widely held view. We might measure changes in justifications in $\alpha$ group of managers within a firm, or in a group of managers across firms. Examples of where we might observe these justifications are such external sources as the business press or such internal sources as prior adopters' presentations to analysts, shareholder meetings, and so forth (King \& Kugler, 2000; Strang \& Soule, 1998).

The persuasiveness of a justification shapes how easily and effectively people make sense of it and, thus, how rapidly the new management practice becomes accepted or taken for granted. From a rhetorical perspective, evidence of acceptance is the lack of a need to linguistically support the practice. Consequently, we can expect an increase in supportive justifications to occur at the beginning of a managerial practice's diffusion and prior to that practice's achieving taken-for-granted status. As the practice becomes more widely diffused and accepted, the frequency and amount of justification should decrease. This increase in justification and diffusion, followed by a decrease in justification without a corresponding decrease in diffusion, indicates a process through which the taken-for-grantedness of a new practice emerges.

Figure 1 shows the behavioral and linguistic implications of a rhetorical theory of diffusion. This model represents the diffusion of $\alpha$ "single practice across a single community (a relationally and culturally connected population)" (Strang \& Soule, 1998: 279). The $\mathrm{x}$-axis represents time, while the first (left) y-axis signifies the percentage of firms within a population that have adopted a managerial practice and the second (right) y-axis shows the amount of justification supporting a managerial practice. The diffusion line represents the actual incidence of behavioral adoption of a managerial practice and is read against the first y-axis. The justification line represents the occurrences of linguistic arguments supporting the adoption of the practice and is read against the second $\mathrm{y}^{-}$ axis.

Figure 1 shows that an increase in diffusion combined with a decrease in justifications approximates an increase in the level of taken-for-grantedness. This suggests that the more compelling and convincing a justification supporting a managerial practice is, the less the justification needs to be repeated or sustained in order to maintain the practice.

FIGURE 1

\section{A Rhetorical Theory of Diffusion}

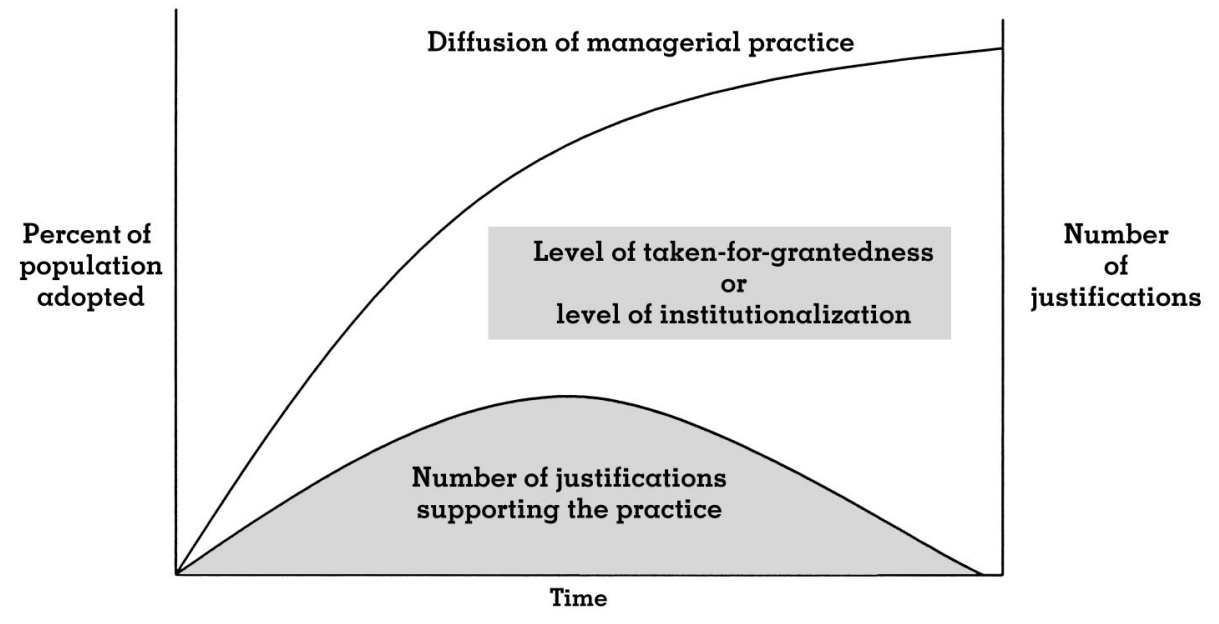


Critical examination of the relationship of justifications and diffusion provides a clearer understanding of institutionalization as both a process and a state. Specifically, institutionalization may take place at many levels (e.g., the individual organizational level or the aggregate level of the organizational field). Over a given period of time, changes in the breadth of diffusion or number of justifications represent the process by which a pattern of action becomes taken for granted or institutionalized. Conversely, at any point in time, the breadth of diffusion relative to the number of justifications represents the state or degree of taken-forgrantedness or institutionalization. For instance, the highest degree of institutionalization is an ideal state of perfect taken-for-grantedness. This reflects 100 percent diffusion of the practice, with no discursive justifications. Connecting these ideas suggests the following proposition.

Proposition 1: The degree of taken-forgrantedness of a managerial practice will be positively related to its breadth of diffusion and negatively related to the number of justifications supporting it.

\section{A Rhetorical View of Diffusion and Our Understanding of Institutions}

Proposition 1 enables us to disentangle takenfor-grantedness from diffusion and to develop a clearer understanding of institutions, institutionalization, and institutional change.

Institutions. Institutionalized practices are those that have become infused with value beyond the technical requirements of the task at hand (DiMaggio \& Powell, 1983; Oliver, 1992; Selznick, 1957). Proposition 1 suggests that in the early stage of institutionalization, when adoption and justifications are both increasing, justifications are actively legitimating and shaping beliefs that the new practices solve recurring practical problems (Berger \& Luckmann, 1966; Homans, 1961; Schutz, 1962). This is consistent with Suchman's (1995) description of pragmatic and moral legitimation as discursive processes that tend to occur early in the institutionalization process (Greenwood et al., 2002; Suchman, 1995), as well as neoinstitutional accounts that early adopters are initially driven by technical/efficiency considerations (Strang \& Macy, 2001; Tolbert \& Zucker, 1983; Westphal, Gulati, \& Shortell, 1997).

Over time, computational and attention limits (Simon, 1945) require a reduction in the cognitive resources attending to the practice; justifications decrease, and the practice's value comes to be taken for granted. This supports Suchman's (1995) idea that cognitive legitimacy represents a lack of discursive justification (Suchman, 1995: 584-585), as well as neoinstitutional formulations that suggest cognitive legitimacy is produced in the later stages of institutionalization (Aldrich \& Fiol, 1994; Greenwood et al., 2002; Tolbert \& Zucker, 1996). In short, in the early process or stage of institutionalization, the practice is discursively asserted to have value and, thus, taken-for-grantedness is low (Greenwood et al., 2002; Suchman, 1995). In the later stages of institutionalization, discourse justifying the value of the practice decreases and taken-forgrontedness is high (Aldrich \& Fiol, 1994; Greenwood et al., 2002; Jepperson, 1991; Suchman, 1995).

Within this framework, the state or degree of institutionalization is equivalent to the degree of taken-for-grantedness (see Figure 1). Scholars note that many things can be taken for granted and that taken-for-grantedness can assume several different forms (Jepperson, 1991: 147-152). However, institutionalization is a special type of taken-for-grantedness, where the value of a proctice is presumed (Jepperson, 1991; Selznick, 1957). Specifically, decreases in justifications may represent a practice that is taken for granted because actors are unaware and have forgotten why it adds value (Jepperson, 1991). Alternatively, decreases in justifications may represent a practice where actors unquestionably accept the practice's value because they lack conscious alternatives (Jepperson, 1991). In either case, justifications have woven a belief about the practice's value into the community's general web of belief (Quine \& Ullian, 1978). The practice appears appropriate and proper and, thus, infused with value beyond its initial technical requirements.

Although a rhetorical theory of diffusion resonates in many ways with neoinstitutional accounts of diffusion, an important difference involves the production of legitimacy and its role in future adoption. Both neoinstitutional (DiMaggio \& Powell, 1983; Tolbert \& Zucker, 1983) and 
rhetorical explanations propose that legitimacy increases future adoption. But neoinstitutional accounts assume a positive relationship between prior adoption and the production of legitimacy (Greenwood et al., 2002; Haunschild \& Miner, 1997; March \& Heath, 1994; Meyer \& Rowan, 1991; Tolbert \& Zucker, 1996), whereas rhetorical theory emphasizes how justifications shape legitimacy.

Both formulations can explain the up-phase in diffusion as either an increase in prior adoption or the outcome of persuasive justifications, but neoinstitutional accounts cannot explain why faddish practices can suddenly develop a negative relationship between prior adoption and legitimacy (Abrahamson \& Fairchild, 1999; Kieser, 1997; Macy \& Strang, 2001). This problem may arise because neoinstitutional explanations imply a perpetual dominance of norms of conformity, where prior adoption always produces legitimacy. The management fashion literature qualifies this claim by suggesting that sometimes norms of progress can dominate, creating a negative relationship between prior adoption and legitimacy (Abrahamson, 1996; Abrahamson \& Fairchild, 1999). Yet why one norm dominates another is left unexplained (Kieser, 1997).

A rhetorical theory of diffusion, however, suggests prior adoption can be discursively interpreted in multiple ways. One manager may justify a popular managerial technique as standard industry practice and, hence, worthy of the firm's adoption, whereas another may question its utility by describing the practice as just another "flavor of the month," incapable of differentiating the firm or increasing its competitive capabilities. In short, a rhetorical view conceptualizes legitimacy as an active product of managerial discourse, whereas many neoinstitutional accounts conceive of legitimacy as a product of prior adoption.

Institutionalization. Proposition 1 also improves our understanding of institutionalization. Neoinstitutionalists often proxy the cognitive form of legitimacy-taken-for-grantedness (Scott, 1995; Suchman, 1995)—with previous adoption (Davis, 1991; Davis \& Greve, 1997; Fligstein, 1985; Palmer, Jennings, \& Zhou, 1993). This conflates diffusion with institutionalizationthe process by which a pattern of action becomes taken for granted (Meyer, Boli, \& Thomas, 1994). Neoinstitutionalists suggest that highly diffused practices are highly institutionalized (Abrahamson \& Fairchild, 1999; Lawrence, Winn, \& Jennings, 2001), and the abandonment of these practices is associated with deinstitutionalization (Lawrence et al., 2001; Oliver, 1992).

However, a management practice can be highly adopted but not highly institutionalized. For example, within the S\&P 1500, over 50 percent have adopted poison pills-a powerful takeover defense used to influence $\alpha$ change-ofcontrol in the firm (Green, 2001). Although this managerial practice is highly diffused, high rates of justification are required to maintain its adoption. This is because the practice is highly contested and for from institutionalized for various constituents (e.g., shareholders, management, board, employees, debtholders) of the firm (Green, 2001). Alternatively, highly institutionalized and highly adopted practices can begin to deinstitutionalize, exhibiting increases in justification, while their level of adoption remains high (e.g., affirmative action programs).

Institutional change. Decoupling diffusion and taken-for-grantedness also provides a useful indicator of when institutional change is more or less likely to occur. Proposition 1 implies that changes in the level of justification may be predictors of institutional change and measures of institutional stability. From this perspective, we can make predictions based on a theoretically limited set of discursive conditions. For example, when justifications are increasing without a corresponding increase in diffusion, institutional change is likely. Conversely, when justifications are decreasing without a corresponding decrease in diffusion, institutional change is unlikely.

Increasing justifications without a corresponding increase in diffusion represents a decline in legitimacy and taken-for-grantedness and, thus, an increase in the probability of institutional change. Specifically, when justifications rise without a corresponding rise in diffusion, institutional orders may be in conflict, signifying alternative and competing choices of action. The justifications lack persuasiveness and are unable to support continued adoption of the practice. In this case, actors bring about change, using the rules and symbols of alternative institutional logics to deviate from normative integration and to achieve individual, political, and organizational variation (Friedland \& 
Alford, 1991; Giddens, 1979; Kuhn, 1996; Swiddler, 1979).

Conversely, when justifications are decreasing without a corresponding decrease in diffusion, two possible cases exist. Either actors are internalizing the rules and symbols of their social system, thus allowing the production of order, conformity, and institutional stability, or the powerful are forcing the adoption of the practice while simultaneously prohibiting public debate. In both cases, the probability of institutional change is very low. In the first instance, actors do not perceive a need to change, and in the second, they do not have the power to implement change.

\section{RHETORICAL JUSTIFICATIONS}

In this section I describe how variation in rhetorical justifications shapes the diffusion process. I first describe three distinct types of rhetorical justifications and develop propositions that describe their effect on the rate of adoption and rejection of managerial practices. While any of these types of appeals may be used in various sequences to influence diffusion, for the sake of space, I delineate one prevalent and influential sequence. I conclude with a description of how these propositions increase our understanding of the active role of managers in the production of rationality and diffusion.

\section{Type and Sequence of Justification}

The pace of adoption and the rejection of managerial practices are important issues for the study of diffusion and institutionalization (Lawrence et al., 2001). A rhetorical theory of diffusion provides a useful conceptual basis to theorize about these issues. Specifically, the rhetorical model developed in Proposition 1 enables us to correlate the content or type of justification with the rate and extent of diffusion. This correlation indicates the persuasiveness of each type of justification and is measured by the degree of taken-for-grantedness exhibited by the practice over time.

Although justifications can take on many different forms (Bies, 1987; Elsbach, 1994; Hirschman, 1991; Lamertz \& Baum, 1998; Scott \& Lyman, 1968; Semin \& Manstead, 1983), rhetorical theorists propose three main types: pathos, logos, and ethos (Aristotle, 1991; Bizzell \& Herzberg,
1990; Herrick, 2001; King \& Kugler, 2000; Nohria \& Harrington, 1994). Pathos justifications impact emotions and are likely to elicit powerful yet unsustainable social action. They may be used, for example, to justify a particular course of action based on a listener's sense of greed or fear. Logos appeals affect the logical part of the mind; they tend to elicit methodical calculation of means and ends to achieve efficiency or effectiveness. Ethos justifications impact moral or ethical sensibilities. They may require sacrificing self-interests for honor, tradition, or justice and are often elicited by the character or credibility of the speaker (Bizzell \& Herzberg, 1990; Herrick, 2001). Moreover, pathos and logos pleas produce pragmatic legitimacy and appeal to an audience's self-interests, whereas ethos justifications produce moral legitimacy and appeal to normative approval and moral propriety (Suchman, 1995). Over time, if these appeals are persuasively effective, they will produce cognitive legitimacy-taken-for-grantedness.

At any given time, a justification may contain all three types of appeals and may be positive or negative. For the purpose of exploring how each appeal affects the speed and breadth of diffusion, as well as the sequence of appeals, I discuss only pure and positive appeals below.

Pathos. Pathos appeals connect with the emotions of individuals (e.g., fear, greed, etc.). They are highly passionate appeals to an audience's self-interest that build and construct pragmatic legitimacy (Suchman, 1995). Rhetorical theory suggests that actors have cognitive and attention limits (Bizzell \& Herzberg, 1990; Guthrie, 1993; Kerferd, 1993; Richords, 1965); thus, individual resistance and group conformity hinder change efforts like the adoption of new practices (Simon, 1945). Emotional appeals have the ability to grab an actor's limited attention, excite the imagination, and direct behavior away from the status quo (King \& Kugler, 2000).

Although initially persuasive, emotional appeals are unable to sustain the limited attention of actors. Thus, practices associated with emotional appeals have transient persuasive power that may exhibit fadlike tendencies (Abrahamson \& Fairchild, 1999). Applying these ideas to diffusion suggests the following.

Proposition 2: A managerial practice supported with pathos justifications 
will have a fast rate of adoption and a fast rate of rejection.

Logos. Logos pleas justify action by appealing to the desire for efficient/effective action and, like pathos, help build pragmatic legitimacy (Suchman, 1995). Whereas pathos appeals are capable of eliciting strong initial reactions, logos justifications are slower at getting actors' attention, because they often require methodical calculation of means and ends (Simon, 1945). Initially, the call for efficiency/effectiveness is less powerful than a pathos appeal (like fear). However, whereas passionate pleas tend to dissipate quickly, appeals to logic are able to sustain their persuasiveness.

Compared to pathos, logos appeals have a slower yet more sustained effect on diffusion, partly because they are socially accepted and admired within the business community (Putnam \& Mumby, 1993). Although logos pleas have a slower persuasive force than pathos appeals, their focus on individual interests gives them a faster effect on persuasion than ethos appeals. Similarly, logos appeals sustain their persuasive effect longer than pathos appeals, yet their social acceptance and, thus, sustainability are less than that of ethos appeals. Therefore, management practices associated with logos appeals should diffuse and be abandoned at slower rates than those supported with pathos appeals, yet at faster rates than ethos appeals.

Proposition 3: A managerial practice supported with logos justifications will have a medium rate of adoption and a medium rate of rejection.

Ethos. Ethos appeals justify action by appealing to socially accepted norms and mores. They produce moral legitimacy that "rests not on judgments about whether a given activity benefits the evaluator, but rather on judgments about whether the activity is the 'right thing to do'" (Suchman, 1995: 579). Ethos appeals are probably the most powerful, with the most enduring impact on taken-for-grantedness (Aristotle, 1991; Herrick, 2001). Whereas pathos and logos justifications emphasize individual concerns and interests, ethos appeals focus on social and collective interests. This emphasis prolongs the time required for ethos pleas to have persuasive effects, because they typically require more complex cognitive processing than direct appeals to individual interests. Ethos appeals may also have a slower persuasive affect because they require the sacrifice of individual interests for social interests.

Although ethos appeals are initially slow to persuade, once an ethos-supported practice is adopted, it becomes difficult to abandon. In a sense, social practices supported by ethos appeals become synonymous with what is right and what is good.

Proposition 4: A managerial practice supported with ethos justifications will have a slow rate of adoption and a slow rate of rejection.

The sequence of rhetoric. Pathos, logos, and ethos appeals may combine to shape the speed and extent of diffusion. Specifically, these three types suggest a rhetorical sequence for highly diffused managerial practices, starting with pathos, followed by logos, and ending with ethos justifications. Each type of appeal has particular characteristics that resonate with specific periods in the life cycle of diffusion. Pathos pleas are based on emotion and, in the beginning of the diffusion process, can capture potential adopters' limited attention and willingness to act. Although emotional energy can help liberate social inertia, it is unlikely to persist. Fortunately, logos appeals can provide managers with persuasive arguments for continuing to adopt managerial practices. Appealing to the desire for effectiveness and efficiency, logos appeals sustain their persuasive power longer than pathos appeals, in large part because these arguments tend to be more socially accepted and admired by management than emotional ones. During the middle stages of diffusion, for example, logos justifications can promote beliefs that the managerial practice works and achieves stated goals, thus encouraging managers to continue adopting it. Finally, ethos arguments have the longest-lasting persuasive effects. Managerial practices supported by ethos appeals become synonymous with what is right and good. They become deeply entrenched and difficult to reject. Thus, ethos arguments can sustain the adoption of managerial practices that have lost their emotional or logical appeal.

Organizational theorists may observe a similar process when they describe successful change efforts. For instance, Kurt Lewin and 
Dorwin Cartwright (1964) argued that successful change in organizations should follow three steps: (1) unfreezing the status quo-change efforts to overcome the pressures of both individual and group conformity; (2) moving to the new state-new behaviors adopted and old behaviors discarded; and (3) refreezing the new change to make it permanent-stabilizing a change intervention by balancing driving and restraining forces. Pathos appeals help direct behavior away from the status quo. Logos appeals link new actions and behaviors to effective outcomes. Ethos appeals lock in new behaviors and hinder movement from the new equilibrium.

Whereas pathos may initiate change, logos implement it, and ethos sustain it, each type of appeal may fit with specific periods in the life cycle of a highly diffused practice. Preliminary evidence supports the plausibility of this rhetorical sequence. In a longitudinal study of the adoption of corporate takeover defenses in North America, I (Green, 2001) found that this popular and highly diffused set of corporate governance practices started with pathos justifications in response to the fear that corporate raiders would pillage the firm. Next, takeover defenses were dominated by logos justifications, which asserted that they helped board members maximize shareholder value and attain the highest price for the firm. Finally, at takeover defenses' broadest levels of diffusion, their adoption was most highly correlated with ethos justifications, which asserted that takeover defenses helped board members perform their duty of protecting stakeholder rights.

A similar pattern appears in the diffusion of total quality management (TQM) in the United States-an admired and highly adopted set of managerial techniques (Lawler, Mohrman, \& Leford, 1992). TQM was initially justified with pathos arguments that predicted American business obsolescence in the face of Japanese economic aggression (Easton, 1993). Next, it was supported with logos appeals, which argued that TQM was a useful and effective managerial practice for improving firm performance (Lawler \& Mohrman, 1985). Later, ethos justifications described how TQM contributed to democratic ideals through employee teamwork and participation in work decisions (Lawler et al., 1992). This preliminary evidence and the ideas discussed above suggest the following proposition.
Proposition 5: A managerial practice for which the diffusion process follows a rhetorical sequence that starts with pathos, moves to logos, and ends with ethos will have a rapid rate of initial adoption, a broad diffusion, and a slow abandonment.

\section{Rhetorical Justifications and Our View of Rationality and Diffusion}

Rhetoric, rationality, and the diffusion process. Propositions 2 through 5 suggest that rationality and, thus, the choices of potential adopters are discursive products. This is a radical change from traditional models of diffusion (neoinstitutional, efficiency, and network), in which it is assumed that rationality is shaped by such factors as social relations, markets, professions, competition, the state, social categories/concepts, and/or fashion markets (Abrahamson, 1996; Burt, 1987; DiMaggio \& Powell, 1983; Douglas, 1986; Granovetter, 1985; Scott, 1995; Simon, 1945; Strang \& Macy, 2001; Strang \& Meyer, 1994). These models are inherently adaptivist because they assume that firms adopt new practices in order to fulfill the need to acquire resources in the technoeconomic environment or to conform normatively to the social environment (Hasselbladh \& Kallinikos, 2000; Hasselbladh \& Theodoridis, 1997). Traditional models also fail to explain why those needs exist or become influential, or why a particular structure fulfills the need in question (Perrow, 1993). The assumption in these models is that practices that satisfy needs are meaningful, and, thus, the adoption of these practices is rational. Yet these formulations underemphasize an actor's capacity to linguistically construct meaning and, thus, obfuscate important facets of organizational life (Pondy \& Mitroff, 1979).

In contrast, proponents of a rhetorical perspective argue that organizational actors are capable of changing what they find meaningful (Aristotle, 1991; Perelman \& Olbrechts-Tyteca, 1969; Quinn, 1996; Toulmin, 1969). They can suppress what are ostensibly the most dominant of needs and participate in hunger strikes, vows of celibacy, and suicide bombings. Thus, actors may find meaningful that which they need, but may also need that which they find meaningful (Booth, 1974; Husserl, 1962; Rubin, 1998). The desire to survive, acquire material wealth and sta- 
tus, or outperform one's competitors does not rationalize the adoption of managerial practices. Managers using pathos, logos, and ethos in conversation with themselves and others rationalize the adoption of a managerial practice and, thus, determine its ultimate breadth of diffusion.

Another important distinction between a rhetorical model of diffusion and traditional models is their differing conceptions of the components of rationality. For example, a rhetorical perspective suggests that emotional justifications (pathos) are an essential component of reasoned argument, as opposed to irrational impediments to decision making (Herrick, 2001; O'Neill, 1997). Culturally, the West has chosen to emphasize the logical aspects of rationality (Putnam \& Mumby, 1993); however, a rhetorical view reminds us that we also calculate with our emotions, suggesting that emotions and rationality are interpenetrated (Ashforth \& Humphrey, 1995; Damasio, 1994; Domagalski, 1999; Fineman, 1996).

This is contrary to traditional diffusion perspectives that treat emotions as pejorative and distinct from rationality (Domagalski, 1999; Putnam \& Mumby, 1993). The management fashion literature, for example, suggests that practices adopted for emotional or social psychological reasons cause managers to irrationally participate in superstitious learning, adopting and rejecting useless solutions to imaginary problems (Abrahamson, 1996; Abrahamson \& Fairchild, 1999). Accordingly, management practices driven by technoeconomic forces are favored in this literature over those motivated by sociopsychological and emotional forces (Abrahamson, 1996). Yet sometimes managers may need to elicit quick and fast action. Firms may be faced with so much organizational inertia or complacency that emotional appeals are the only effective way to get actors' attention and to get energy mobilized for change. These ideas resonate with descriptions of successful social and political movements that often use emotional appeals to elicit effective social action (Gamson \& Meyer, 1996; Hirschman, 1991). A rhetorical theory of diffusion in general, and Propositions 2 and 5 in particular, suggest that emotional appeals can be effective, appropriate, and rational components of the adoption decision.

Similarly, a rhetorical perspective emphasizes the importance of discourse about ethics in adoption decisions. Traditional models of diffusion often overemphasize the importance of the logical aspects of rationality, at the expense of ethical and moral sensibilities. Failing to recall the Ford Pinto and systemically hiding the effects of tobacco are prime examples of where managers may have overemphasized the logical components of their decision making and, thus, adopted practices lacking sufficient moral and ethical reasoning (Birsch \& Fielder, 1994; Mitroff \& Anagnos, 2000). Propositions 4 and 5 highlight the important role ethics plays in the spread and stability of organizational practices.

Rhetoric and the active role of managers. A rhetorical theory of diffusion proposes that institutional change and stability are functions of rhetorical strategies, suggesting a view of diffusion that includes an active role for the manager, without being too undersocialized. Managers are seen as constructing justifications from endoxa-commonly held or taken-for-granted premises. These appeals are then used to support, advocate, and implement new behaviors and ideas, which, if successful, may themselves become taken for granted. This explains how culture and discourse, with their complex web of commonly accepted premises and meanings, restrict the choices available to actors (Aristotle, 1991; Burke, 1969; Perelman \& Olbrechts-Tyteca, 1969; Quine \& Ullian, 1978). Yet a rhetorical perspective also underscores the indeterminacy and agentic possibilities of organizational life and, thus, the ability of proactive managers to use commonly accepted premises in new and inventive ways to modify available choices (Aristotle, 1991; Burke, 1969; Perelman \& OlbrechtsTyteca, 1969; Quine \& Ullian, 1978; Wittgenstein, 1963).

In sum, a rhetorical perspective restores agency. Rhetoric is used more or less artfully to change things, so it is rich precisely where theory is most needed: the interconnection of structure and agency. The application of a rhetorical perspective to diffusion is just on illustration of this more general point.

\section{DISCUSSION AND CONCLUSION}

In this section I first discuss the implications of a rhetorical theory of diffusion for our understanding of diffusion and the behavior of organizations. I then describe potential future research within the context of the model pre- 
sented. I conclude with a discussion of the main points of a rhetorical theory of diffusion and highlight the importance of studying language for organizational research.

\section{Implications of a Rhetorical Theory of Diffusion}

A rhetorical theory of diffusion enhances our understanding of how managerial practices diffuse. Managers and managerial scientists spend enormous resources and energy searching for and creating new practices. Some of these practices thrive and become broadly diffused and accepted, whereas others dissipate and disappear as fast as they arrive. Although organizational scholars propose that diffusion is shaped by a variety of factors (Greve, 1995; Oliver, 1992; O'Neill et al., 1998), most of their explanations gravitate toward realist concerns while underemphasizing the role of linguistic factors (Strong \& Meyer, 1994). Moreover, neoinstitutionalists often emphasize the persistence and endurance of diffused practices while ignoring their dissipation and rejection (Oliver, 1992). In contrast, a rhetorical theory of diffusion shows how the spread and dissipation of managerial practices depend on the sequence and type of rhetoric. Specifically, pathos, logos, and ethos justifications shape the rationality underlying both the adoption and rejection of managerial practices.

A rhetorical theory of diffusion also highlights the active role of managers in organizational change and behavior. For instance, neoinstitutionalists assume that managers' cognitive and attention limits allow their rationality to be shaped by the organizational environment (Powell \& DiMaggio, 1991). Within this framework, managers passively adhere to the dominant cultural and discursive guidelines of legitimate behavior (Friedland \& Alford, 1991; Powell \& DiMaggio, 1991). In contrast, a rhetorical perspective emphasizes how actors' cognitive limits enable the agentic use of discourse (Bizzell \& Herzberg, 1990; Guthrie, 1993; Kerferd, 1993; Richards, 1965). From a rhetorical perspective, cognitive limits allow for the active and intentional use of discourse to construct organizational problems, solutions, and goals. This resonates with more agentic conceptions of managers, cognitive limits, and discourse (Ford \& Ford,
1995; Friedland \& Alford, 1991; Oswick, Keenoy, \& Gront, 1997; Perrow, 1993).

\section{Implications for Future Research}

Finally, rhetorical theory identifies several critical areas for future research. A popular perspective in diffusion theory emphasizes the role of social structure in shaping diffusion patterns (Burt, 1987; Coleman, Katz, \& Menzel, 1966; Granovetter \& Soong, 1983; Macy \& Strang, 2001; Schelling, 1978; Strang \& Meyer, 1994; Valente, 1996). The rhetorical view suggests a more radical conceptualization of social structure in the diffusion process. Instead of an assumption that social structure is independent of and exists prior to rhetoric, social structure is seen as something that is shaped and constructed by discourse.

For example, the rhetoric of TQM advocates that firms adopting TQM change both the structure and content of their supplier relationships. The rhetoric of TQM encourages firms to choose supplier relationships based on quality as opposed to just price and to decrease the total number of suppliers in favor of a smaller set of long-term relationships (Deming, 1986; Hackman \& Wageman, 1995; Ishikawa, 1985; Juran, 1974). TQM rhetoric also admonishes firms to decrease the variation in their production process by demanding that firms supplying important inputs adopt TQM practices and procedures (Deming, 1986; Hackman \& Wageman, 1995; Ishikawa, 1985; Juran, 1974). This TQM rhetoric constructs and shapes social structure and, thus, the diffusion of the practice itself.

Many ideologies in our society demonstrate similar rhetorical properties. For instance, the rhetoric of proselytizing religions like Christionity suggests that telling others about Christionity is a good deed that can increase the chance of getting to heaven. Thus, adherents to the Christian faith are rhetorically encouraged to engage in missionary and proselytizing activities that create and establish new social relationships in order to further spread Christion beliefs and practices (Dawkins, 1976; Lynch, 1996). In future studies researchers could examine the rhetorical viral and mimetic properties of managerial discourse.

A second critical area for future research concerns the relationship between rhetoric and outcomes. Several organizational theorists have 
commented on how discourse may bring performance gaps to the attention of managers and shape their beliefs about the efficacy of particular managerial practices (Abrahamson \& Fairchild, 1999; Strang, 1991; Zbaracki, 1998). At the core of these descriptions is the assumption that the speed and breadth of diffusion are positively related to how well a managerial practice decreases performance gaps (Abrahamson, 1991; O'Neill et al., 1998; Thirtle \& Rutton, 1987). A rhetorical theory of diffusion is consistent with the view that discourse shapes the beliefs and attention of actors; however, it suggests that the discourse justifying a practice may construct the world in such a way that the "real" effects of the practice conform to its description.

For example, managerial capitalism or managerial control of the firm is legitimated by discourse that suggests managers have superior knowledge of the firm. However, the very nature of managerial control enables managers to accumulate the knowledge they are described as having in the first place (Chandler, 1977; Green, 2001; Taylor, 1911). Even if managers initially lack superior knowledge of the firm, once they are in control, they use their positions to acquire greater knowledge. Thus, the legitimacy of their authority increases in a positive feedback loop. In a sense, the rhetoric of a new practice becomes the reality of that practice. In future research scholars might examine the link between the rhetoric of a practice and the reality of that practice in order to shed light on how language as a form of action (Austin, 1975) shapes and affects organizations.

Additionally, a rhetorical theory of diffusion has implications for research on the role of uncertainty and power in the diffusion of managerial practices. Many theorists have conceptualized uncertainty as playing an important role in the diffusion process (Abrahamson \& Rosenkopf, 1993; DiMaggio \& Powell, 1983; Haunschild \& Miner, 1997; March \& Olsen, 1979; Pfeffer, Salancik, \& Leblebici, 1976; Rogers, 1995). Similarly, in several studies researchers have elaborated on the important role of power in the adoption of a practice (Baron, Dobbin, \& Jennings, 1986; Dobbin, Edelman, Meyer, Scott, \& Swiddler, 1988; Oliver, 1991; O'Neill et al., 1998). However, these formulations underemphasize the effects of cognitive limits on power (Perrow, 1993).
Rhetorical theory can increase understanding of this process. If the cognitive limits of those in power place them in an ambiguous and uncertain world, then they might not know what actions actually benefit them (Perrow, 1993). They might not know that certain courses of action are more efficient than others. They may not even know the potential of their own power. This ambiguity allows for the influence of rhetorically savvy consultants, academics, and corporate actors. Rhetorically gifted takeover entrepreneurs can galvanize shareholders in the takeover of the firm, and rhetorically adept union leaders can persuade workers to organize strikes and work stoppages. To the skillful rhetoricion, the ambiguity social actors face is fertile ground for the active construction of interests and the courses of action supporting them (Gamson \& Meyer, 1996; Hirschman, 1991). In future studies researchers can clarify how rhetoric mediates and shapes the role of power and uncertainty in the diffusion process. This might explain the spread of practices as varied as employee stock ownership programs and hostile two-tier bids.

Researchers might also examine the effect of both positive and negative rhetoric within discourse. For instance, in the early stage of diffusion, practices supported with positive pathos rhetoric and criticized with negative ethos rhetoric may diffuse differently from practices supported with positive pathos rhetoric and criticized with negative logos rhetoric. Laboratory studies using variation in rhetorical justifications as interventions could shed light on these dynamics. Additionally, further research is needed to address the diffusion of practices across heterogeneous populations or different discursive environments, and whether the diffusion of different types of practices is more or less associated with different types of rhetorical justifications. Research is also needed to explore the differences between the capacities of individual actors to use or be moved by different types of justifications. Understanding variation in these individual capacities may provide important insight into diffusion, leadership, and organizational change.

\section{Conclusion}

Rhetorical theory provides a unique analytical framework for the study of organizational 
issues. Examining diffusion from a rhetorical perspective enables the decoupling of diffusion from institutionalization. It demonstrates that highly adopted practices are not necessarily highly institutionalized. Sometimes highly adopted practices require justifications to maintain their adoption. At other times, practices are highly adopted because those with power force them on others.

Rhetorical theory also enhances the development of diffusion measures and, therefore, addresses limitations of existing diffusion theories. For instance, in neoinstitutional theory it is difficult to measure taken-for-grantedness, which is a central feature of neoinstitutional explanations (Donaldson, 1995; Hasselbladh \& Kallinikos, 2000; Zucker, 1987). Proposition 1 defines the degree of taken-for-grantedness as a function of two measurable constructs: diffusion (percent of population adopting the practice) and justifications (the number of appeals supporting the practice). It also shows how different types of justifications can produce different types of legitimacy. By extending our ability to focus on indicators of institutionalization, rhetorical theory provides a means to observe and measure institutional forces at various levels of analysis-from small groups to populations of firms. It can also be applied to different types of practices-from the adoption of new technologies to the adoption of structural forms.

Moreover, a rhetorical theory of diffusion allows us to critically examine the dynamic relationship between justifications and diffusion and, thus, understand institutionalization as both a process and a state. Changes in the breadth of diffusion or number of justifications define the process by which a pattern of action becomes taken for granted or institutionalized. In addition, the breadth of diffusion relative to the number of justifications represents the state or degree of taken-for-grantedness or institutionalization.

Most important, a rhetorical theory of diffusion highlights the causal potency of language in shaping organizational life and behavior. It advocates the study and use of language for helping researchers better understand organizations. Moreover, rhetorical theory portrays the manager as rhetor and suggests that his or her most influential tool is language.

\section{REFERENCES}

Abrahamson, E. 1991. Managerial fads and fashions: The diffusion and rejection of innovations. Academy of Management Review, 16: 586-612.

Abrahamson, E. 1996. Management fashion. Academy of Management Review, 21: 254-285.

Abrahamson, E. 1997. The emergence and prevalence of employee-management rhetorics: The effect of long waves, labor unions, and turnover, 1875 to 1992. Academy of Management Journal, 40: 491-533.

Abrahamson, E., \& Fairchild, G. 1999. Management fashion: Lifecycles, triggers and collective learning processes. Administrative Science Quarterly, 44: 708-740.

Abrahamson, E., \& Rosenkopf, L. 1993. Institutional and competitive bandwagons: Using mathematical modeling as a tool to explore innovation diffusion. Academy of Management Review, 18: 487-518.

Aldrich, H., \& Fiol, C. 1994. Fools rush in? The institutional context of industry creation. Academy of Management Review, 19: 645-670.

Alvesson, M., \& Körreman, D. 2000. Taking the linguistic turn in organizational research: Challenges, responses, consequences. Journal of Applied Behavioral Science, 36: $136-158$.

Aristotle 1991. The art of rhetoric. New York: Penguin Books.

Ashforth, B. E., \& Humphrey, R. H. 1995. Emotion in the workplace: A reappraisal. Human Relations, 48: 97-125.

Astley, W. G., \& Zammuto, R. F. 1992. Organization science, managers, and language games. Organization Science, 3: $443-460$.

Austin, J. L. 1975. How to do things with words. Cambridge, MA: Harvard University Press.

Bakhtin, M. 1981. The dialogic imagination. Austin, TX: University Press.

Barley, S. R., \& Kunda, G. 1992. Design and devotion: Surges of rational and normative ideologies of control in managerial discourse. Administrative Science Quarterly, 37: 363-399.

Barley, S. R., \& Tolbert, P. S. 1997. Institutionalization and structuration: Studying the links between action and institution. Organization Studies, 18: 93-117.

Baron, J. N., Dobbin, F. R., \& Jennings, P. D. 1986. War and peace: The evolution of modern personnel administration in U.S. industry. American Journal of Sociology, 92: 350-383.

Berger, P., \& Luckmann, T. 1966. The social construction of reality: $A$ treatise in the sociology of knowledge. New York: Doubleday.

Bies, R. J. 1987. The predicament of injustice: The management of moral outrage. Research in Organizational Behavior, 9: 289-319.

Billig, M. 1996. Arguing and thinking: A rhetorical approach to social psychology. Cambridge: Cambridge University Press.

Birsch, D., \& Fielder, J. H. 1994. The Ford Pinto case: A study 
in applied ethics, business, and technology. Albany: State University of New York Press.

Bizzell, P., \& Herzberg, B. (Eds.). 1990. The rhetorical tradition: Readings from classical times to the present. Boston: Bedford Books of St. Martin's Press.

Booth, W. 1974. Modern dogma and the rhetoric of assent. Chicago: University of Chicago Press.

Burke, K. 1969. A rhetoric of motives. Berkeley: University of California Press.

Burt, R. S. 1987. Structural contagion and innovation: Cohesion versus structural equivalence. American Journal of Sociology, 92: 1287-1335.

Carson, P., Lanier, P., Carson, K., \& Guidry, B. 2000. Clearing a path through the management fashion jungle: Some preliminary trailblazing. Academy of Management Journal, 43: 1143-1159.

Chandler, A. D. 1977. The visible hand: The managerial revolution in American business. Cambridge, MA: Belknap Press of Harvard University Press.

Coleman, J. S., Katz, E., \& Menzel, H. 1966. Medical innovation: A diffusion study. Indianapolis: Bobbs-Merrill.

Damasio, A. R. 1994. Descartes' error: Emotion, reason, and the human brain. New York: Putnam.

Dandridge, T. C., Mitroff, I., \& Joyce, W. F. 1980. Organizational symbolism: A topic to expand organizational analysis. Academy of Management Review, 5: 77-82.

Davis, G. 1991. Agents without principles? The spread of the poison pill through the intercorporate network. Administrative Science Quarterly, 36: 583-590.

Davis, G., \& Greve, H. 1997. Corporate elite networks and governance changes in the 1980's. American Journal of Sociology, 103: 1-37.

Dawkins, R. 1976. The selfish gene. Oxford: Oxford University Press.

Deming, E. 1986. Out of crisis. Cambridge, MA: Massachusetts Institute of Technology, Center for Advanced Engineering Study.

DiMaggio, P., \& Powell, W. 1983. The iron cage revisited: Institutional isomorphism and collective rationality in organizational fields. American Sociological Review, 48: 147-160.

Dobbin, F. R., Edelman, L., Meyer, J. W., Scott, W. R., \& Swiddler, A. 1988. The expansion of due process in organizations. In L. G. Zucker (Ed.), Institutional patterns and organizations: Culture and environments: 71-100. Cambridge, MA: Ballinger.

Domagalski, T. 1999. Emotion in organizations: Main currents. Human Relations, 52: 833-852.

Donaldson, L. 1995. American anti-management theories of organization: A critique of paradigm proliferation. Cambridge: Cambridge University Press.

Douglas, M. 1986. How institutions think. Syracuse, NY: Syracuse University Press.

Easton, G. S. 1993. The 1993 state of U.S. total quality management: A Baldridge examiner's perspective. California Management Review, 35(3): 32-55.
Eccles, R., Nohria, N., \& Berkley, J. D. 1992. Beyond the hype: Rediscovering the essence of management. Boston: Harvard Business School Press.

Elsbach, K. D. 1994. Managing organizational legitimacy in the California cattle industry: The construction and effectiveness of verbal accounts. Administrative Science Quarterly, 39: 57-88.

Fairclough, N. 1992. Discourse and social change. Cambridge, MA: Polity Press.

Fineman, S. 1996. Emotion and organizing. In S. Clegg, C. Hardy, \& W. Nord (Eds.), The handbook of organization studies: 543-564. Thousand Oaks, CA: Sage.

Fligstein, N. 1985. The structural transformation of American industry: An institutional account of the causes of diversification in the largest firms. In W. W. Powell \& P. J. DiMaggio (Eds.), The new institutionalism in organizational analysis: 311-336. Chicago: University of Chicago Press.

Ford, J. D., \& Ford, L. W. 1995. The role of conversations in producing intentional change in organizations. Academy of Management Review, 20: 541-570.

Friedland, R., \& Alford, R. 1991. Bringing society back in: Symbols, practices, and institutional contradictions. In W. W. Powell \& P. J. DiMaggio (Eds.), The new institutionalism in organizational analysis: 223-262. Chicago: University of Chicago Press.

Gamson, W. A., \& Meyer, D. S. 1996. Framing political opportunity. In D. McAdam, J. D. McCarthy, \& M. N. Zald (Eds.), Comparative perspectives on social movements: Political opportunities, mobilizing structures, and cultural framings: 275-290. Cambridge: Cambridge University Press.

Garfinkel, H. 1967. Studies in ethnomethodology. Englewood Cliffs, NJ: Prentice-Hall.

Gergen, K. J. 1994. Realities and relationships: Soundings in social construction. Cambridge, MA: Harvard University Press.

Gergen, K. J., \& Thatchenkery, T. J. 1996. Organization science as social construction: Postmodern potentials. Journal of Applied Behavioral Science, 32: 356-377.

Giddens, A. 1979. Central problems in social theory: Action, structure and contradiction in social analysis. Berkeley: University of California Press.

Gill, A. M., \& Whedbee, K. 1997. Rhetoric. In T. A. van Dijk (Ed.), Discourse as structure and process: Discourse studies: A multidisciplinary introduction: 157-184. Thousand Oaks, CA: Sage.

Granovetter, M. 1985. Economic action and social structure: The problem of embeddedness. American Journal of Sociology, 91: 481-510.

Granovetter, M., \& Soong, R. 1983. Threshold models of diffusion and collective behavior. Journal of Mathematical Sociology, 9(3): 165-179.

Grant, D., Keenoy, T., \& Oswick, C. 1998. Discourse and organization. Thousand Oaks, CA: Sage.

Green, S. Jr., 2001. Rhetoric and the institutionalization of takeover defenses in the S\&P 1500 from 1975-1998. Un- 
published doctoral dissertation, Harvard University Graduate School of Business, Boston.

Greenwood, R., Suddaby, R., \& Hinings, C. R. 2002. Theorizing change: The role of professional associations in the transformation of institutionalized fields. Academy of Management Journal, 45: 58-80.

Greve, H. 1995. Jumping ship: The diffusion of strategy abandonment. Administrative Science Quarterly, 40: 444-473.

Guthrie, W. K. C. 1993. The sophists. Cambridge: Cambridge University Press.

Habermas, J. 1984. The theory of communicative action. Boston: Beacon Press.

Hackman, R., \& Wageman, R. 1995. Total quality management: Empirical, conceptual, and practical issues. Administrative Science Quarterly, 40: 309-342.

Hasselbladh, H., \& Kallinikos, J. 2000. The project of rationalization: A critique and reappraisal of neo-institutionalism in organization studies. Organization Studies, 21: 697-720.

Hasselbladh, H., \& Theodoridis, F. 1997. Social magmas and the conventional explanatory pyramid. Scandinavian Journal of Management, 14(1-2): 53-76.

Haunschild, P. R., \& Miner, A. S. 1997. Modes of interorganizational imitation: The effects of outcome, salience, and uncertainty. Administrative Science Quarterly, 42: 472-500.

Herrick, J. A. 2001. The history and theory of rhetoric: An introduction. Boston: Allyn and Bacon.

Hirsch, P. 1986. From ambushes to golden parachutes: Corporate takeovers as an instance of cultural framing and institutional integration. American Journal of Sociology, 91: 800-837.

Hirschman, A. 1991. The rhetoric of reaction. Cambridge, MA: Belknap Press of Harvard University Press.

Homans, G. C. 1961. Social behavior: Its elementary forms. New York: Harcort, Brace \& World.

Huff, A. S. 1983. A rhetorical examination of strategic change. In L. R. Pondy, P. J. Frost, G, Morgan, \& T. C. Dandridge (Eds.), Organizational symbolism: 167-183. Greenwich, CT: JAI Press.

Husserl, E. 1962. Ideas: General introduction to pure phenomenology. New York: Collier.

Ishikawa, K. 1985. What is total quality control? The Japanese way. Englewood Cliffs, NJ: Prentice-Hall.

Jepperson, R. L. 1991. Institutions, institutional effects, and institutionalism. In W. W. Powell \& P. J. Dimaggio (Eds.), The new institutionalism in organizational analysis: 146-163. Chicago: University of Chicago Press.

Juran, J. M. 1974. The quality control handbook (3rd ed.). New York: McGraw-Hill.

Kerferd, G. B. 1993. The sophistic movement. Cambridge: Cambridge University.

Kieser, A. 1997. Rhetoric and myth in management fashion. Organization: The Interdisciplinary Journal of Organization, Theory, and Society, 4(1): 49-74.
King, W. R., \& Kugler, J. L. 2000. The impact of rhetorical strategies on innovation decisions: An experimental study. Omega, 28: 485-499.

Krackhardt, D. 2001. Viscosity models and the diffusion of controversial innovation. In A. Lomi \& E. Larsen (Eds.), Dynamics of organizations: Computational modeling and organization theories: 243-268. Menlo Park, CA: AAAI Press/MIT Press.

Kuhn, T. S. 1996. The structure of scientific revolutions. Chicago: University of Chicago Press.

Lamertz, K., \& Baum, J. A. C. 1998. The legitimacy of organizational downsizing in Canada: An analysis of explanatory media accounts. Canadian Journal of Administrative Sciences, 15(1): 93-107.

Lawler, E., III, \& Mohrman, S. 1985. Quality circles after the fad. Harvard Business Review, 63(1): 65-71.

Lawler, E., III, Mohrman, S., \& Leford, G. J. 1992. Employee involvement and total quality management. San Francisco: Josey-Bass.

Lawrence, T. B., Winn, M. I., \& Jennings, P. D. 2001. The temporal dynamics of institutionalization. Academy of Management Review, 28: 624-644.

Lewin, K., \& Cartwright, D. 1964. Field theory in social science. New York: Harper \& Row.

Lynch, A. 1996. Thought contagion: How belief spreads through society. New York: Basic Books.

Macy, M., \& Strang, D. 2001. Dedicated followers of success: A computational model of fashionable innovations. In A. Lomi \& E. Larsen (Eds.), Dynamics of organizations: Computational modeling and organization theories: 93117. Menlo Park, CA: AAAI Press/MIT Press.

March, J. G., \& Heath, C. 1994. A primer on decision making: How decisions happen. New York: Free Press.

March, J. G., \& Olsen, J. P. 1979. Ambiguity and choice in organizations. Bergen: Universitetsforlaget.

McCloskey, D. N. 1998. The rhetoric of economics. Madison: University of Wisconsin Press.

Meyer, J., \& Rowan, B. 1991. Institutionalized organizations: Formal structure as myth and ceremony. In W. W. Powell \& P. J. DiMaggio (Eds.), The new institutionalism in organizational analysis: 41-62. Chicago: University of Chicago Press.

Meyer, J. W., Boli, J., \& Thomas, G. M. 1994. Ontology and rationalization. In R. Scott \& J. Meyer (Eds.), Institutional environments and organizations: Structural complexity and individualism: 9-27. Thousand Oaks, CA: Sage.

Mintzberg, H. 1973. The nature of managerial work. New York: Harper \& Row.

Mitroff, I. I., \& Anagnos, G. 2000. Managing crises before they happen: What every executive and manager needs to know about crisis management. New York: Amacom.

Nohria, N., \& Harrington, B. 1994. The rhetoric of change. Research note No. 9-494-036. Cambridge, MA: Harvard Business School.

Oliver, C. 1991. Strategic responses to institutional processes. Academy of Management Review, 16: 145-179. 
Oliver, C. 1992. The antecedents of deinstitutionalization. Organization Studies, 13: 568-588.

O'Neill, H. M., Pouder, R. W., \& Buchholtz, A. K. 1998. Patterns in the diffusion of strategies across organizations: Insights from the innovation diffusion literature. Academy of Management Review, 23: 98-114.

O'Neill, J. 1997. Rhetoric, science, and philosophy. Philosophy of the Social Sciences, 28(2): 205-225.

Oswick, C., Keenoy, T., \& Grant, D. 1997. Managerial discourses: Words speak louder than actions? Journal of Applied Management Studies, 6(1): 5-12.

Palmer, D. A., Jennings, P. D., \& Zhou, X. 1993. Late adoption of the multidivisional form by large U.S. corporations: Institutional, political, and economic accounts. Administrative Science Quarterly, 38: 100-131.

Perelman, C., \& Olbrechts-Tyteca, L. 1969. The new rhetoric: A treatise on argumentation. Notre Dame: University of Notre Dame Press.

Perrow, C. 1993. Complex organizations: $A$ critical essay. New York: McGraw-Hill.

Pfeffer, J. 1981. Management as symbolic action. Research in Organizational Behavior, 3: 1-51.

Pfeffer, J., Salancik, G. R., \& Leblebici, H. 1976. The effect of uncertainty on the use of social influence in organizational decision making. Administrative Science Quarterly, 21: 227-245.

Pondy, L. R., \& Mitroff, I. I. 1979. Beyond open systems of organization. Research in Organizational Behavior, 1: 3-39.

Powell, W. W., \& DiMaggio, P. J. 1991. Introduction. In W. W. Powell \& P. J. DiMaggio (Eds.), The new institutionalism in organizational analysis: 1-38. Chicago: University of Chicago.

Putnam, L., \& Mumby, D. 1993. Organizations, emotion and the myth of rationality. In S. Fineman (Ed.), Emotions in organizations: 36-57. London: Sage.

Quine, W. V., \& Ullian, J. S. 1978. The web of belief. New York: Random House.

Quinn, K. 1996. A rhetorical conception of practical rationality. Journal of Economic Issues, 30: 1127-1142.

Richards, I. A. 1965. The philosophy of rhetoric. London: Oxford University Press.

Rogers, E. M. 1995. Diffusion of innovations. New York: Free Press.

Rorty, R. 1980. Philosophy and the mirror of nature. Princeton, NJ: Princeton University Press.

Rubin, E. 1998. Putting rational actors in their place: Economics and phenomenology. Vanderbilt Law Review, 51: 1705-1727.

Schelling, T. C. 1978. Micromotives and macrobehavior. New York: Norton.

Schutz, A. 1962. Collected papers: The problems of social reality. The Hague: Marinuw Nijhorr.

Scott, M. B., \& Lyman, S. M. 1968. Accounts. American Sociological Review, 33: 46-92.
Scott, R. W. 1995. Institutions and organizations. Thousand Oaks, CA: Sage.

Selznick, P. 1957. Leadership in administration: $A$ sociological interpretation. New York: Harper \& Row.

Semin, G. R., \& Manstead, A. S. R. 1983. The accountability of conduct: A social psychological analysis. London \& New York: Academic Press, published in cooperation with the European Association of Experimental Social Psychology.

Simon, H. 1945. Administrative behavior. New York: Free Press.

Strang, D. 1991. Adding social structure to diffusion models: An event history framework. Sociological Methods and Research, 19: 324-353.

Strang, D., \& Macy, M. W. 2001. In search of excellence: Fads, success stories, and adaptive emulation. American Journal of Sociology 107: 147-182.

Strang, D., \& Meyer, J. W. 1994. Institutional conditions for diffusion. In R. W. Scott \& J. W. Meyer (Eds.), Institutional environments and organizations: Structural complexity and individualism: 100-111. Thousand Oaks, CA: Sage.

Strang, D., \& Soule, S. A. 1998. Diffusion in organizations and social movements: From hybrid corn to poison pills. Annual Review of Sociology, 24: 265-290.

Suchman, M. C. 1995. Managing legitimacy: Strategic and institutional approaches. Academy of Management Review, 20: 571-610.

Swiddler, A. 1979. Culture and action: Symbols and strategies. American Sociological Review, 51: 273-286.

Taylor, F. W. 1911. The principles of scientific management. New York: Horper Brothers.

Thirtle, C. G., \& Rutton, V. W. 1987. The role of demand and supply in the generation and diffusion of technical change. Chur, Switzerland \& New York: Harwood Academic.

Tolbert, P. S., \& Zucker, L. 1983. Institutional sources of change in the formal structure of organizations: The diffusion of civil service reform 1880-1935. Administrative Science Quarterly, 30: 22-39.

Tolbert, P. S., \& Zucker, L. G. 1996. The institutionalization of institutional theory. In S. R. Clegg, C. Hardy, \& W. Nord (Eds.), Handbook of organization studies: 175-190. Thousand Oaks, CA: Sage.

Toulmin, S. E. 1969. The uses of argument. Cambridge: Cambridge University Press.

Valente, T. W. 1996. Social network thresholds in the diffusion of innovations. Social Networks, 18: 69-89.

van Dijk, T. A. 1997. Discourse studies: A multidisciplinary introduction. London, Sage.

Watson, T. J. 1995. Rhetoric, discourse and argument in organizational sense making: A reflexive tale. Organization Studies, 16: 805-821.

Weick, K. 1972. The social psychology of organizing. Reading, MA: Addison-Wesley.

Westphal, J. D., Gulati, R., \& Shortell, S. M. 1997. Customi- 
zation or conformity? An institutional and network perspective on the content and consequences of TQM adoption. Administrative Science Quarterly, 42: 366394.

Wittgenstein, L. 1963. Philosophical investigations. Oxford: Blackwell.

Zald, M. N. 1996. More fragmentation? Unfinished business in linking the social sciences and the humanities. Administrative Science Quarterly, 41: 251-264.
Zbaracki, M. 1998. The rhetoric and reality of total quality management. Administrative Science Quarterly, 43: 602-636.

Zucker, L. 1987. Institutional theories of organization. Annual Review of Sociology, 13: 443-464.

Zucker, L. 1991. The role of institutionalization in cultural persistence. In W. W. Powell \& P. J. DiMaggio (Eds.), The new institutionalism in organizational analysis: 83-107. Chicago: University of Chicago Press.

Sandy Edward Green, Jr., is an assistant professor of management at the University of Southern California, Los Angeles. He received his Ph.D. from the Harvard University Graduate School of Business. His current research interests include neoinstitutional theory, rhetorical theory, and corporate governance. 
Copyright of Academy of Management Review is the property of Academy of Management and its content may not be copied or emailed to multiple sites or posted to a listserv without the copyright holder's express written permission. However, users may print, download, or email articles for individual use. 